\title{
DESAIN KONSTRUKSI MEJA BETON PENYANGGA POWER TRANSFORMER 80 MVA PT KDL CILEGON
}

\author{
Widayat Amariansah $^{1^{*}}$, Soehartono Soehartono ${ }^{2}$ \\ ${ }^{1,2}$ Prodi Teknik Sipil Universitas Pandanaran \\ Jalan Banjarsari Barat no.1, Pedalangan, Banyumanik, Semarang \\ Email*:widayat62@gmail.com
}

\begin{abstract}
ABSTRAK
PT Krakatau Daya Listrik (KDL) merupakan anak perusahaan PT Krakatau Steel (Persero) Tbk yang berfungsi membangkitkan energi listrik dari PLTU 5x80 MW milik sendiri dan menyalurkannya melalui jaringan transmisi $150 \mathrm{kV}$ dan distribusi $30 \mathrm{kV}, 20 \mathrm{kV}, 6 \mathrm{kV}, 400 \mathrm{~V}$ ke seluruh industri, kantor dan perumahan karyawan di lingkungan Krakatau Industrial Estate Cilegon-Banten. Untuk meningkatkan keandalan dan jumlah pasokan listriknya, PT KDL membangun Main Transfer Station unit IV (MTS IV) yang berfungsi sebagai gardu induk yang menerima, mengatur dan mendistribusikan suplai listrik dari PLTU ke masing-masing pabrik. MTS IV terdiri dari bangunan gedung kontrol $30 \mathrm{kV}$ dan bangunan penyangga power transformer 3x80 MVA yang berimpit di dekatnya. Kedua bangunan ini dipisahkan dengan sistem dilatasi. Struktur beton penyangga power transformer 3x80 MVA ini berbentuk meja yang mempunyai 3 ruang untuk setiap transformer. Setiap ruang terdiri dari 1 lantai dasar dan 2 lantai basement yang dirancang untuk menahan berat setiap transformer sebesar 115 ton.
\end{abstract}

Kata kunci : Beton, bangunan penyangga, power transformer

\begin{abstract}
PT Krakatau Daya Listrik (KDL) is a subsidiary company of PT Krakatau Steel (Persero) Tbk that functions to generate electricity from self owned power plant $5 \times 80 \mathrm{MW}$ and distribute it through $150 \mathrm{kV}$ transmission line and distribution $30 \mathrm{kV}, 20 \mathrm{kV}, 6 \mathrm{kV}, 400 \mathrm{~V}$ line to all industries, offices and residential employees in Krakatau Industrial Estate Cilegon-Banten. To improve the reliability and the amount of electricity supply, PT KDL was construct Main Transfer Station unit IV (MTS IV) as new substation that receive, manage and distribute electricity from the power plant to industrial area. MTS IV consists of $30 \mathrm{kV}$ control building and buffer structure for 3x80 MVA power transformers that are nearby separated with dilatation system. The buffer concrete structure for 3x80 MVA power transformers are like tables which have 3 rooms for each transformer. Each room consist of 1 ground floor and 2 basement to support a 115 tons transformer effectively.
\end{abstract}

Keywords: Concrete, buffer structure, power transformer. 


\section{PENDAHULUAN}

Konstruksi beton penyangga power transformer (trafo) di area MTS IV terdiri dari 3 ruang yang masing-masing diisi transformer 80 MVA seberat 115 ton. Setiap ruang dipisahkan oleh dinding api beton (firewall) setebal $25 \mathrm{~cm}$ setinggi $9 \mathrm{~m}$ untuk mencegah penjalaran api ke trafo lainnya jika satu trafo meledak dan terbakar. Lantai dasar (ground floor) trafo pada EL. 0.00 direncanakan setebal $30 \mathrm{~cm}$ dan di bawahnya terdapat 2 basement yaitu pada El. -1.50 untuk cable duct dan saluran air hujan serta pada El. -4.75 untuk perletakan underground cable duct (UGC) $150 \mathrm{kV}$ dari pembangkit yang masuk ke gedung kontrol $30 \mathrm{kV}$. Dinding basement setebal $25 \mathrm{~cm}$ berfungsi menahan tekanan tanah dan tekanan air laut yang diprediksi terintrusi sampai kawasan Krakatau Industrial Estate Cilegon. Firewall direncanakan mampu menahan tekanan angin 70 $\mathrm{kg} / \mathrm{m}^{2}$ setara dengan kecepatan angin $120 \mathrm{~km} / \mathrm{jam}$. Perhitungan gempa menggunakan SNI 03-28472002 yang memasukkan Cilegon dalam zona gempa dengan respon spektra percepatan gempa 0,40.g menurut Peta Gempa Indonesia Juli 2010 dari Kementerian PU.

\section{METODOLOGI}

Beban yang bekerja pada bangunan penyangga transformer MTS IV terdiri dari beban mati (DL), beban hidup (LL), beban angin (W), beban gempa (E) dan beban lain yang disyaratkan vendor elektromekanikal dan PT KDL. Beban mati (DL) terdiri dari berat sendiri struktur atas gedung dan berat peralatan elektromekanikal. Beban hidup (LL) sebesar $500 \mathrm{~kg} / \mathrm{m} 2$ untuk lantai basement dan $2000 \mathrm{~kg} / \mathrm{m} 2$ untuk lantai dasar tempat power transformer diletakkan. Beban angin (W) menggunakan referensi Pedoman Pembebanan Bangunan Gedung Indonesia 1987 untuk bangunan khusus industri dengan mempertimbangkan data meteorologi BMKG setempat 10 tahun terakhir. Beban gempa sesuai SNI 03-2847-2002 tentang Tata Cara Perhitungan Struktur Beton Bangunan Gedung, sedangkan beban lain mengikuti spesifikasi teknis PT PLN, PT KDL dan vendor elektromekanikal yang ditunjuk. Sebagai contoh beban dinamis akibat getaran mesin sebesar 20\% dari berat sendiri peralatan. Kombinasi beban struktur atas yang dipilih mengacu pada SNI 03 2847-2002 yaitu :

- Comb. $1=1,40 . \mathrm{DL}$

- Comb. $2=1,20 . \mathrm{DL}+1,60 . \mathrm{LL}$

- Comb.3 = 1,20.DL + 1,00.LL + 1,00.E(x)+ 1,30.W(x)

- Comb.4 = 1,20.DL + 1,00.LL + 1,30.E(x)+ $1,00 . \mathrm{W}(\mathrm{x})$

- Comb.5 = 1,20.DL + 1,00.LL $+1,30 \cdot \mathrm{E}(\mathrm{y})+$ $1,00 . \mathrm{W}(\mathrm{y})$

- Comb.6 = 1,20.DL + 1,00.LL + 1,00.E(y) + 1,30.W(y)

Dari hasil perhitungan 6 kombinasi beban tersebut dihasilkan reaksi perletakan pondasi (support reaction) pada arah $\mathrm{x}, \mathrm{y}$ dan $\mathrm{z}$ di setiap titik pondasi yang terdiri dari gaya vertikal, angkat, horizontal dan momen. Desain pondasi menggunakan kelompok tiang pancang beton yang dihitung daya dukungnya berdasarkan nilai N-SPT dan tekanan konus qc. Selain gaya reaksi perletakan akibat beban struktur atas, pondasi juga direncanakan mampu menahan gaya gempa, gaya gesek negatif akibat material timbunan di atasnya dan sifat tanah setempat yang merupakan lanau kepasiran, pergeseran lateral kepala tiang, lendutan dan tekuk tiang pancang, penurunan, gaya angkat serta keruntuhan blok.

\section{HASIL DAN PEMBAHASAN}

Konstruksi dan fasad bangunan harus tahan karat, asam, basa dan sulfat namun tetap mempertimbangkan keselarasan dengan bangunan dan lingkungan sekitarnya yang merupakan kawasan industri strategis dan obyek vital nasional di tepi pantai Cilegon, Jawa Barat. Konfigurasi struktur bangunan menggunakan sistem plat-balok untuk menahan beban vertikal. Sedangkan untuk menahan beban lateral digunakan Sistem Rangka Pemikul Momen Biasa (SRPMB) dari rangka beton bertulang dengan pondasi tiang pancang beton sehingga bangunan direncanakan terjepit lateral pada pondasi. Perhitungan gaya, momen, dimensi elemen struktur dan tulangan menggunakan program SAP 2000 versi 7.42 dan Microsoft Excel 2007. Struktur bangunan atas menggunakan beton K.300 dan tulangan baja ulir U.40, sedangkan 
struktur bawah menggunakan tiang pancang beton persegi K.450 ukuran $25 \times 25 \mathrm{~cm} 2$. Hasil pemodelan struktur atas dan bawah disajikan dalam gambar 1 dan 2 .

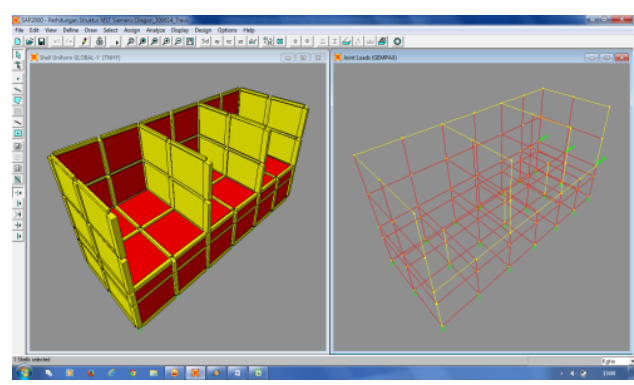

Gambar 1. Pemodelan struktur atas

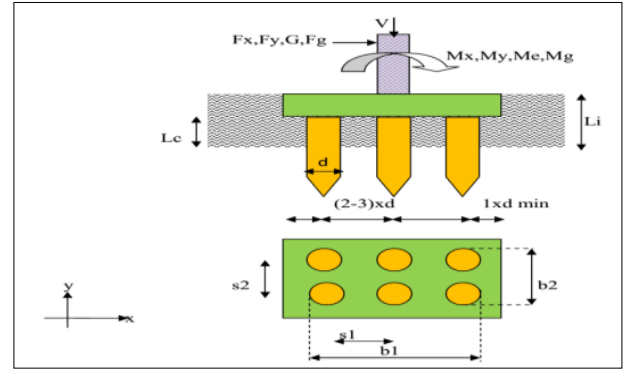

Gambar 2. Pemodelan struktur bawah

Tabel 1. Hasil perhitungan struktur atas

\begin{tabular}{|c|c|c|c|c|c|}
\hline No & Komponen & Plat & Balok Induk & Balok Anak & Kolom \\
\hline I. & Lantai dasar EL. \pm 0.00 & & & & \\
\hline a. & Ukuran & tebal $=0,30 \mathrm{~m}$ & $0,30 \times 0,60$ & $0,30 \times 0,40$ & $0,40 \times 0,60$ \\
\hline b. & Tulangan pokok & $\begin{array}{c}\begin{array}{c}\text { D13-125 } \\
\text { (dobel) }\end{array} \\
\end{array}$ & $8 \mathrm{D} 25$ & $5 \mathrm{D} 25$ & $16 \mathrm{D} 25$ \\
\hline c. & Tulangan lateral & - & $\Phi 10-100$ & $\Phi 10-150$ & $\Phi 10-150$ \\
\hline II. & Lantai basement EL. -1.50 & & & & \\
\hline a. & Ukuran & tebal $=0,20 \mathrm{~m}$ & $0,30 \times 0,60$ & $0,30 \times 0,40$ & $0,40 \times 0,60$ \\
\hline b. & Tulangan pokok & $\begin{array}{c}\text { D13-150 } \\
\text { (dobel) }\end{array}$ & $8 \mathrm{D} 25$ & $5 \mathrm{D} 25$ & $16 \mathrm{D} 25$ \\
\hline c. & Tulangan lateral & - & $\Phi 10-100$ & $\Phi 10-150$ & $\Phi 10-100$ \\
\hline III. & Lantai basement EL. -4.75 & & & & \\
\hline a. & Ukuran & tebal $=0,20 \mathrm{~m}$ & $0,30 \times 0,60$ & $0,30 \times 0,40$ & $0,40 \times 0,60$ \\
\hline b. & Tulangan pokok & $\begin{array}{c}\begin{array}{c}\text { D13-150 } \\
\text { (dobel) }\end{array} \\
\end{array}$ & $8 \mathrm{D} 25$ & $5 \mathrm{D} 25$ & $16 \mathrm{D} 25$ \\
\hline c. & Tulangan lateral & - & $\Phi 10-100$ & $\Phi 10-150$ & $\Phi 10-100$ \\
\hline IV. & Fire wall EL. \pm 0.00 & & & & \\
\hline a. & Ukuran & $\begin{array}{c}\text { tinggi }=9,00 \mathrm{~m} \\
\text { tebal }=0,30 \mathrm{~m}\end{array}$ & $0,30 \times 0,40$ & - & $0,40 \times 0,60$ \\
\hline b. & Tulangan pokok & $\begin{array}{c}\text { D13-150 } \\
\text { (dobel) }\end{array}$ & $5 \mathrm{D} 25$ & - & $16 \mathrm{D} 25$ \\
\hline c. & Tulangan lateral & - & D13-150 & - & $\Phi 10-100$ \\
\hline V. & $\begin{array}{l}\text { Dinding basement } \\
\text { EL. } \pm 0.00 \mathrm{sd}-4.75\end{array}$ & & & & \\
\hline a. & Ukuran & tebal $=0,25 \mathrm{~m}$ & - & - & - \\
\hline b. & Tulangan pokok rangkap & $\begin{array}{c}\text { D13-150 } \\
\text { (dobel) }\end{array}$ & - & - & - \\
\hline c. & Tulangan lateral & - & - & - & - \\
\hline
\end{tabular}


Tabel 2. Hasil perhitungan struktur bawah

\begin{tabular}{|r|l|c|c|}
\hline \multicolumn{1}{|c|}{ No } & \multicolumn{1}{|c|}{ Komponen } & Pile cap & Kolom/T.Pancang \\
\hline I. & Pile cap & & \\
\hline a. & Ukuran & $1,45 \times 1,45 \times 0,60$ & $0,40 \times 0,60$ \\
\hline b. & Tulangan pokok atas & D19-200 & - \\
\hline c. & Tulangan pokok bawah & D19-150 & - \\
\hline d. & Tulangan pokok & - & $16 \mathrm{D} 25$ \\
\hline e. & Tulangan lateral & - & $\Phi 10-100$ \\
\hline II. & Tiang pancang & - & $0,25 \times 0,25$ \\
\hline a. & Ukuran & - & $5 @ 4,00 \mathrm{~m}$ \\
\hline b. & Jumlah dan panjang & - & $4 \mathrm{D} 13$ \\
\hline c. & Tulangan pokok & - & $\Phi 6-100$ \\
\hline d. & Tulangan lateral & \\
\hline III. & Kestabilan pile group & & 34,89 ton \\
\hline a. & Daya dukung ijin / tiang & & $0,83 \mathrm{~cm}$ \\
\hline b. & Defleksi ijin & & $0,90 \mathrm{tm}$ \\
\hline c. & $\begin{array}{l}\text { Momen kapasitas pile } \\
\text { head }\end{array}$ & & $9,84 \mathrm{~cm}$ \\
\hline d. & Penurunan total & & 1,07 \\
\hline e. & FS keruntuhan blok & & \\
\hline
\end{tabular}

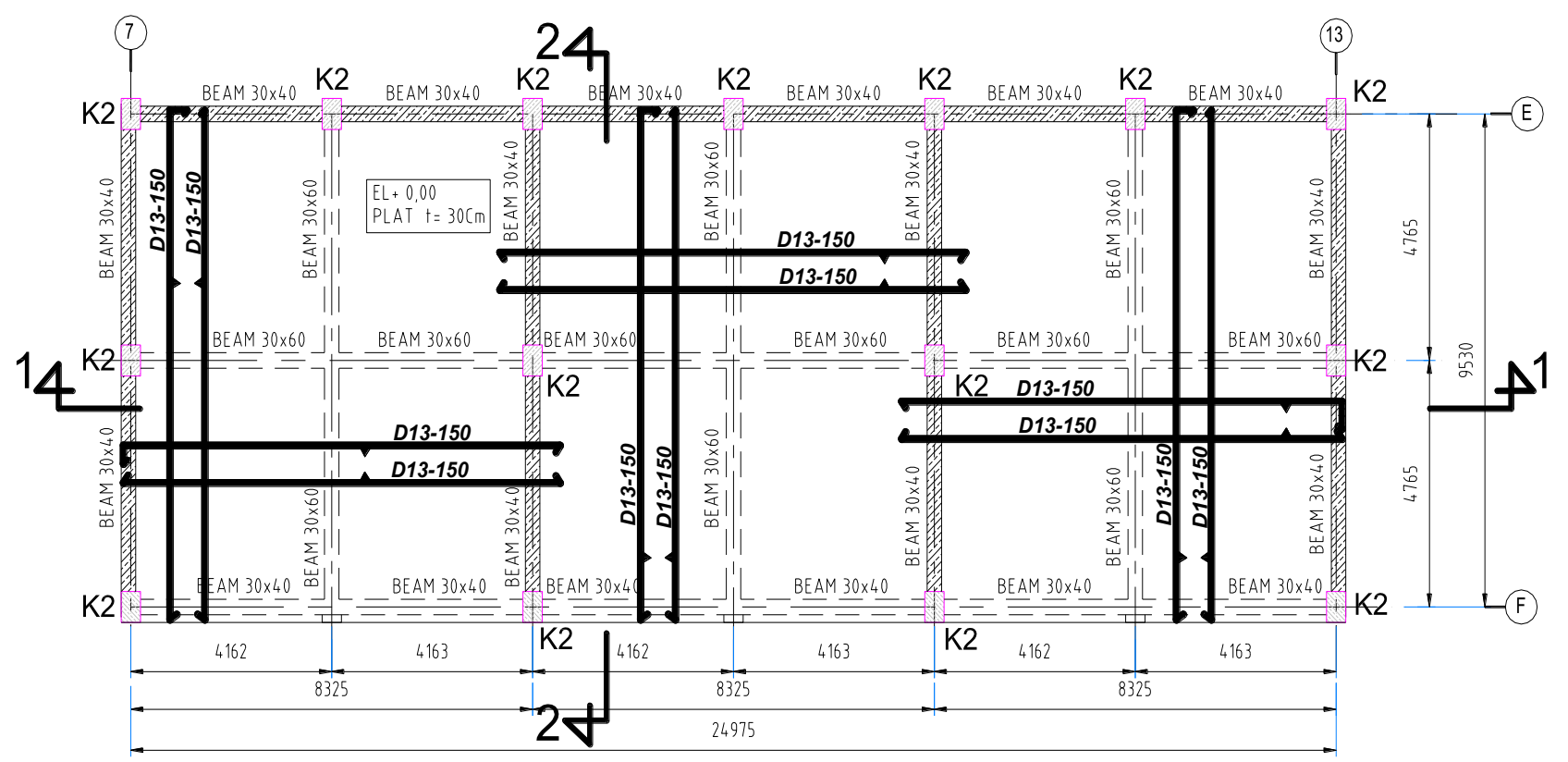

Gambar 3. Penulangan lantai dasar EL. \pm 0.00 


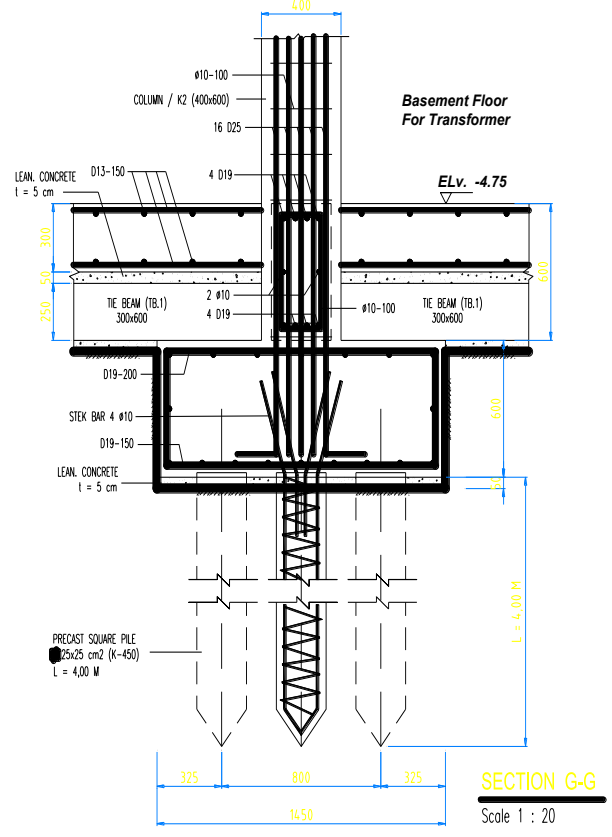

Gambar 4. Detail pondasi tiang pancang $25 \times 25 \mathrm{~cm}^{2}$

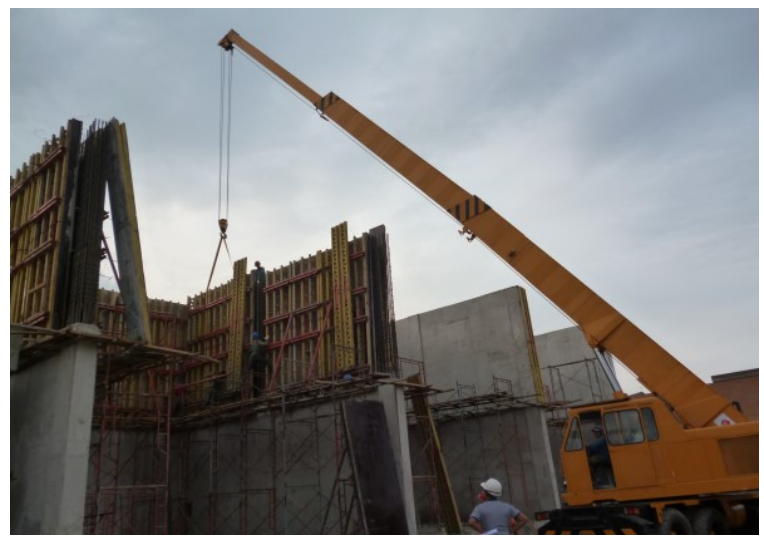

Gambar 5. Pengecoran lantai, dinding dan fire wall

\section{SIMPULAN}

Struktur atas bangunan beton penyangga power transformer 80 MVA terdiri dari 3 ruang berbentuk meja yang masing-masing dipisahkan firewall beton setinggi $9 \mathrm{~m}$ dari ground floor. Setiap ruang mempunyai 3 lantai yaitu 1 lantai dasar dan 2 lantai basement. Struktur bawah bangunan menggunakan pondasi tiang pancang beton $0,25 \times 0,25 \mathrm{~m}^{2}$ yang ditanam sedalam $7 \mathrm{~m}$ dari muka tanah rencana atau $4 \mathrm{~m}$ dari lantai basement ke dua. Aspek penurunan tanah menjadi hal utama yang perlu diwaspadai karena lokasi bangunan terletak di dataran rendah dekat Samudera Indonesia dan Selat Sunda yang merupakan jalur pertemuan lempeng Asia dan Australia sehingga rawan terjadi gempa tektonik.

\section{DAFTAR PUSTAKA}

Beton, WIKA, 2011, PC Spun Pile Technical Specification, WIKA, Jakarta.

Christady, Hary, Hardiyatmo., 2006, Teknik Pondasi Jilid 1 dan 2, Beta Offset, Yogjakarta.

Departemen PU, 1989, Tata Cara Perencanaan Pembebanan untuk Rumah dan Gedung, SNI 03-1727-1989, Yayasan LPMB, Bandung.

Ibid, 2003, Perhitungan Beton Bertulang Tahan Gempa Indonesia, SNI 03-2847-2002, Yayasan LPMB, Bandung.

Electrical Engineering Services Centre, 2011, Technical Requirement Standards for Civil and Structural Works or Transmission and Substation, Electrical Engineering

Services Centre, Jakarta.

Siemens-KDL, 2014, General Arrangement and Layout of KDL Blast Furnace Project, PT KDL, Cilegon.

Petrosol, 2012, Soil Investigation Report for Main Transformer Substation IV, PT KDL, Cilegon.

Suyono, Nakazawa, 1984, Mekanika Tanah dan Teknik Pondas, Pradnya Paramita, Jakarta. 